\title{
The Future of Research in Strategy Implementation in the BRICS Context
}

\author{
Geovana Alves de Lima Fedato ${ }^{\dagger}$ \\ UNEMAT \\ Vanessa Martins Pires ${ }^{\Omega}$ \\ UNISINOS \\ Guilherme Trez \\ UNISINOS
}

\begin{abstract}
Albeit the development of the capacity to implement strategic change being a challenge to modern organizations, the studies in this area have prioritized intern issues of the organization, relegating it as a secondary plan, the contextual factors. Implementing a new strategy implies in the alignment of resources and internal capabilities to the organizational reality, adjusting them to the needs or external impositions. Thus, this study aims to identify research suggestions on strategy implementation and relate them to the characteristics of the countries belonging to the BRICS, through a systematic review. In order to meet this goal, the coevolution perspective was used to support the discussion of strategy implementation, stimulating reflections on the role of management and the environment in the context of strategic change. Academically speaking, the results point to an update on the research agenda on implementation strategy; at the managerial level, we present insights for managers of companies operating or that intend to settle in the BRICS countries.
\end{abstract}

Keywords: Strategy implementation; BRICS; Coevolution.

\section{INTRODUCTION}

Considering the phenomenon of globalization, organizations have sought break through borders, entering new markets. This international competition has significant impact on the practice of management and strategy researchers (SCHENDEL, 1991). Adjusting a balance between environment and strategy is present in organizational studies, and when it comes to strategy formation, deterministic and indeterministic prospects are considered. Bignetti and Paiva (2002) explain that in the deterministic view decision makers accept the external environment as given and immutable and act internally to compensate for external influences; in the indeterministic view however, the organization, run by its decision makers, is not regarded as a passive actor: it can also influence the structure and change the environment. These views stem from institutional theory or the theory of strategic choice.

Research on core institutional approach consider that the adaptation to the environment ensures survival and longevity to the organization.

Corresponding author: ${ }^{\dagger}$ UNEMAT

E-mail: geovana@unemat-net.br

$\Omega$ UNISINOS

E-mail: vmpires@unisinos.br

${ }^{¥}$ UNISINOS

E-mail: gtrez@unisinos.br

Received: 08/20/2015.

Revised: $11 / 14 / 2015$.

Accepted: 01/10/2016

Published Online: 02/01/2017

DOI: http://dx.doi.org/10.15728/bbr.2017.14.3.2 
In this perspective, organizations need to constantly evaluate their actions and adapt to the marketing context, fulfilling the requirements of this environment. On the other hand, there are theorists who argue that the ruling coalition plays a preponderant role in determining the strategies and, through political schemes and negotiations they act in the environment and can even determine it (CHILD, 1997).

However, a new logic emerges in organizational studies, as a counterpoint to these alternatives: the coevolutionary view. Lewin and Volberda (1999) present the perspective of coevolution as a new lens to reintegrate organizational theory and strategy, for according to the authors it is necessary to combine multiple analysis lenses for the study of strategy in the organization.

In the approach proposed in this study we consider the synergy between environment and management, in advocating that strategic management is an inherently contextual activity, because managers develop their strategies according to the environment in which they operate, being able to change, as well as being changed by the environment (JARZABKOWSKI, 2005).

From the point of view of the strategic approach, we highlight two significant moments: i) strategy formulation (development and planning) and ii) implementation of the strategy (put into action). The strategy is also emergent, i.e., the result of a process, in which it may not be planned, as proposed by Mintzberg (1985). And even in agreeing that there is a close relationship between the formulation and implementation of strategy (LEONARDI, 2015), it is necessary for the desired cropping in this research, focusing on the characteristics of a stage: the implementation. This fact does not mean strengthening the dichotomy of thinkers and doers (fact that has been reported by current research strategy), nor, if one considers that strategy is the result of a stagnant stage, but simply that the studies on implementation focus on internal organizational characteristics that the company explores, to develop the ability to implement changes, or new strategies, foreseeing that the desired results are achieved.

The strategic change can be defined as a change in an organization strategy content, in an effort to align or to comply with environmental opportunities and threats, resulting in an organization of cognitive orientation (GUIETTE; VANDENBEMPT, 2013). Thus, understanding the implementation of the strategy helps to understand the adjustments that are needed for new strategies to be implemented.

As strategy implementation consist in making resources and capabilities suitable in order to achieve objectives and targets set, the management of such resources and capabilities requires not only the adaptation to the organization's internal environment, but also to its external environment. In this sense, $\mathrm{Xu}$ and Meyer (2013) describe that emerging economies provide a laboratory to investigate the interaction between business strategies and local contexts, stressing the importance of studying the theme on strategy, considering the relationships that occur inside and outside the organizational environment in different contexts.

From the contextual point of view, we observe that globalization has provided not only increased competition between companies and nations, but also influenced the cooperation between them, by forming alliances, such as the components of the BRICS countries. The reality of the emerging markets, which are the countries belonging to the BRICS, among others, presents a challenge to the academy, due to the economic representation and contextual differences that are present in these markets (CHIRCU; MAHAJAN, 2009; MCCARTHY ET AL., 2012).

It is known that emerging markets have expanded quite rapidly in recent years, creating new spaces for goods and services. This expansion requires that companies know these markets that differ from those of developed countries, and those of which a greater economic growth is expected in a near future (SHETT, 2011). 
BBR

14,3

Thus, this study is a literature review with the objective of identifying the advances and suggestions of research proposed by strategy implementation authors, over the last ten years (2004-2014). By means of the coevolution perspective, we will present as a context the BRICS alliance, from the point of view of social, economic, cultural and ethnical characteristics, so that in the final analysis we may be able to draw a parallel, between the characteristics of this scenario and research suggestions raised in the studies on strategy implementation.

The desired contribution resulting from this study has relevance at two different moments. First, we present an update on the research agenda on strategy implementation; on the other hand, to explore the context of the BRICS alliance, we characterize this important group of emerging countries whose economic, social, cultural and ethnical characteristics are still poorly researched. With this information at hand, the work presents as a contribution the parallel: the horizon of research in strategy implementation and the BRICS scenario, inferring on how organizations wishing to compete in those markets can prepare or organize themselves.

Regarding the structure of the work, this introduction we present the objective and justification of the study; the next chapter covers the methodology used in this systematic review. In the following chapters we address the strategy implementation thematic, being the research suggestions by authors of this theme, as well as characteristics of the BRICS. Following, we conduct a discussion on the research suggestions, considering the BRICS characteristics. Finally, we describe the final considerations and references used in this study.

\section{RESEARCH METHODOLOGY}

This study includes a systematic review methodology, a which uses as a data source the literature on a particular topic, by applying explicit and systematic methods of search, critical appraisal and synthesis of selected information. The proposed steps for conducting a systematic review are: defining the objective of the review, identifying the literature and selecting studies to be included in the research (SAMPAIO; MANCINI, 2007).

Consulting and obtaining the articles in this study were conducted in the following databases: EBSCO Host and Web of Science. The search for articles was conducted in three stages, which can be detailed as:

- $\quad 1^{\text {st. }}$ stage: using the term "strateg* implementation", in the title and the terms: BRIC; BRICS and "emergent markets", in the title and abstract, in the search for articles;

- $\quad 2^{\text {nd }}$. stage: delimitation of research, considering the area of knowledge: social sciences; matters relating to the research objective; the period of time covered by the study: 2004-2014; languages: English or Portuguese; and only complete texts, present in scientific journals;

- $\quad 3^{\text {rd }}$. stage: research refinement, considering the impact factor of the journals. We used the Journal Citation Reports (JCR) of 2014 and we kept in the sample only the items that have an impact factor equal to or greater than 1 .

After conducting the described research stages, we obtained a total number of 64 articles, with 39 studies related to the strategy implementation thematic and 25 studies related to the BRICS.

In both cases, the title, abstract and keywords of each article were read, to identify those who met the purpose of this research. A final refinement was needed, to exclude from the sample articles related to strategy implementation in the public sector, as well as third sector organizations, as this study aims to analyze the strategy implementation thematic, considering the implications for private sector organizations, operating for profit. 
Finally, we selected 44 articles for analysis, 29 relating to the strategy implementation thematic, and 15 that address the characteristics of countries comprising the BRICS. After the selecting the articles that make up the sample, observed a section devoted to future research suggestions on each article, as well as introduction and final considerations sections, in studies on strategy implementation in order to identify research gaps and/or research suggestions, proposed by the authors. For the articles related to the BRICS, we conducted a full reading of each study.

The selected articles focusing on strategy implementation, are distributed in 19 journals and are listed in Table 1. Those that discuss on the BRICS are distributed in 10 journals, duly listed in Table 2 . All the articles analyzed in the systematic review were highlighted in the references with an asterisk (*)to make it possible to identify the publication details.

\section{IMPLEMENTATION STRATEGY: INTERNAL AND EXTERNAL FACTORS}

Implementing strategic change is one of the most important undertakings in the organization (SONENSHEIN, 2010) and is configured in many organizations as routine and not as a pre-planned process. In the case of planned strategic change, this was long seen as a task of formal leaders, under a voluntary perspective. However, we must recognize that the environment also interferes with the process of change. In fact, according to the view by Machado-da-Silva, Fonseca and Fernandes (1998) there must be an integration in which the environment can be considered as a requirement for the development of the internal capacity of strategic choice.

Lewin and Volberda (1999) present the perspective of coevolution as a new lens to reintegrate the organizational theory and strategy. The authors return to the theory of strategic choice, population ecology, institutionalism and evolutionist theories, explaining the environmental or managerial intentionality. The authors conclude that despite the merits of each theory, we need to consider a multilevel perspective, because with single lens approaches, it was not possible to progress in studies on adaptation and selection. Progress requires combining and recombining multiple lenses, rather than fragmentation, since adaptation and selection are not completely opposing forces, but fundamentally interlinked.

Coevolution is the joint result of the intentionality of management and environmental effects (LEWIN; VOLBERDA, 1999) and its properties are: multilevel (consider the internal effects and between firms); multidirectional causality (organizations coevolve); nonlinearity (the ways of feedback are indeterminate, i.e., changes in one variable cause undetermined changes in another variable); positive feedback (organizations influence their environments and the environment influences the organization in a recursive two-way view of mutual causality) and dependence on the history and trajectory (adaptation is dependent on the organization's history and trajectory).

We note that through this lens, we can study strategy implementation as a concept that includes both choice and environmental adaptation (MACHADO-DA-SILVA; FONSECA; FERNANDES, 1998). This perspective represents an advance over existing approaches, since implementation studies were often poorly developed in relation to strategic planning, beyond the dominance of European and American models (KAZMI, 2008).

In the study by Noble, the term strategy implementation is related to control and monitoring; to the implementation of strategic plans; planning involving resource allocation and to operational problems resolving, being of an eclectic nature. From these combinations, the author conceives implementation as "communication, interpretation, adoption and execution of strategic plans" (NOBLE, 1999, p. 120). For Smith (2009), this definition has prescriptive content. For Mintzberg, Ahlstrand and Lampel (2000), the strategy results not from a plan, but it is emerging. 
BBR

14,3

292

Table 1. Studies on strategy implementation

\begin{tabular}{|c|c|c|}
\hline AUTHORS/YEAR & JOURNAL & FI JCR (2014) \\
\hline \multicolumn{3}{|c|}{ STRUCTURAL VIEW } \\
\hline Ye, Marinova, Singh (2007) & Journal of Marketing & 3,938 \\
\hline \multicolumn{3}{|l|}{ Kleinbaum and Stuart (2014) } \\
\hline Gary (2005) & Strategic Management Journal & 3,341 \\
\hline \multicolumn{3}{|l|}{ Nixon et al. (2004) } \\
\hline Fryxell, Butler and Choi (2004) & Journal of World Business & 2,388 \\
\hline Bhimani and Langfield-Smith (2007) & Management Accounting Research & 2,125 \\
\hline Naranjo-Gil and Hartmann (2007) & Health Policy & 1,907 \\
\hline Pinkse, Kuss and Hoffmann (2010) & International Business Review & 1,713 \\
\hline Brenes, Mena and Molina (2008) & Journal of Business Research & 1480 \\
\hline Lin and Hsieh (2010) & Journal of Business Research & 1,480 \\
\hline Wallace, Johnson and Umesh (2009) & Decision Sciences & 1,347 \\
\hline Crittenden and Crittenden (2008) & & 1163 \\
\hline Slater, Olson and Hult (2010) & Business Horızons & 1,163 \\
\hline \multicolumn{3}{|c|}{ INTERPERSONAL VIEW } \\
\hline Sonenshein (2010) & Academyof Management Journal & 6,448 \\
\hline Klingebiel and Meyer (2013) & \multirow{2}{*}{ Organization Science } & \multirow{2}{*}{3,775} \\
\hline Sonenshein (2009) & & \\
\hline O'Reilly et al. (2010) & Leadership Quarterly & 3,138 \\
\hline Hakonsson et al. (2012) & Long Range Planning & 2,718 \\
\hline Harrington (2006) & $\begin{array}{l}\text { International Journal of Hospitality Ma- } \\
\text { nagement. }\end{array}$ & 1,939 \\
\hline Micheli, Mura and Agliati (2011) & $\begin{array}{l}\text { International Journal of Operations \& } \\
\text { Production Management. }\end{array}$ & 1,736 \\
\hline Ho, Wu and $\mathrm{Wu}(2014)$ & Accounting, Organizations and Society & 1,672 \\
\hline $\begin{array}{l}\text { Homburg, Krohmer and Workman Jr. (2004); } \\
\text { Chimhanzi and Morgan (2005) }\end{array}$ & Journal of Business Research & 1,480 \\
\hline Kazmi (2008) & Management Decision & 1,429 \\
\hline Ogbeide and Harrington (2011) & $\begin{array}{c}\text { International Journal of Contemporary } \\
\text { Hospitality Management }\end{array}$ & 1,407 \\
\hline Guiette and Vandenbempt (2013) & European Management Journal & 1,222 \\
\hline \multicolumn{3}{|c|}{ INDIVIDUAL VIEW } \\
\hline Sonenshein and Dholakia (2012) & \multirow{2}{*}{ Organization Science } & \multirow{2}{*}{3,775} \\
\hline Klingebiel and Meyer (2013) & & \\
\hline Huy (2011) & Strategic Management Journal & 3,341 \\
\hline
\end{tabular}

Source: The authors, (2015).

\subsection{CENTRAL ASPECTS OF RESEARCH IN STRATEGY IMPLE- MENTATION}

For the study of the implementation phenomenon, considering that there are many variables involved, several classifications are proposed in the literature (KAZMI, 2008; NOBLE, 1999; NOBLE AND MOKWA, 1999). This study uses as a reference the classification developed by Noble and Mokwa (1999). According to these authors, the research in implementation strategy is grouped into three categories: structural view, interpersonal 
Table 2. Studies on BRICS

\begin{tabular}{lcc}
\hline AUTHORS/YEAR & JOURNAL & FI JCR (2014) \\
\hline Zhang, Li e Li (2014) & American Management Journal & 6,448 \\
Purkayastha, Manolova e Edelman & International Journal of Management Reviews & 3,857 \\
$(2012)$ & Strategic Management Journal & 3,341 \\
Ho, Wu e Xu (2011) & Strategic Management Journal & 3,341 \\
Zhang et. al (2010) & Management and OrganizationReview & 2,442 \\
Li, Chen e Shapiro (2013) & World Development & 1,965 \\
Snowden e Muñoz (2012) & International Journal of Research in Marketing & 1,575 \\
Strizhakova e Coulter (2013) & Journal of Product Innovation Management & 1,572 \\
Chircu e Mahajan (2009) & Journal of Finance and Quantitative Analysis & 1,566 \\
Ayyagari, Kunt e Maksimovic (2011) & 1,326 \\
Li e Zhang (2010) & Journalof Business Ethics & 1,326 \\
McCarthy et. al (2012) & Journalof Business Ethics & 1,326 \\
Ye e Zhang (2011) & Journalof Business Ethics & 1,326 \\
Zhang e Rezaee (2009) & Journalof Business Ethics & 1,326 \\
Zhou, Han e Wang (2013) & Journalof Business Ethics \\
Chan e Daim (2012) & Futures & 1,012 \\
\hline Souce The & & \\
\hline
\end{tabular}

BBR

14,3

293

process view and individual view. The structural view includes research on the effects of various structures and control systems on organizational processes; the interpersonal process view considers studies on the effects of strategic consensus and autonomy, the diffusion of organizational innovations, leadership and implementation style and the effects of communication processes on performance; and the individual level contemplates issues related to cognition, organizational roles and commitment.

Table 1 shows the items included in each category, according to Noble and Mokwa (2009). Following, we discuss their contributions.

We believe that the classification contributes to the identification of each author's focus of analysis although it should not be considered as being inflexible. In addition, there is a certain interdependence and complementarity in the approaches, since according to Noble and Mokwa (1999), the implementation results from both the individual and organizational level.

\section{- Structural View}

The relationship between organizational structure and implementation is pointed out by Noble and Mokwa (1999) as a necessary precursor to the successful implementation of new business strategies. The organizational structure is understood as a permanent configuration of tasks and activities (SKIVINGTON; DAFT, 1991).

Slater, Olson and Hult (2010) argue that the elements of organizational architecture structure, systems and culture - encourage and shape behaviors for implementation. Brenes, Mena, and Molina (2008) point out the recruitment and development of talented employees as a top management's key function fully aligned with the company's strategy, setting the course of action and carrying out its tasks, as expected.

Studies present in the sample contribute to a better understanding of which organizational capabilities are needed to implement strategies: a) Crittenden and Crittenden (2008) gather critical structure and levels of managerial skills to build the organizational capacity; b) the study by Lin and Hsieh (2010) highlights three organizational capabilities that have 
BBR

14,3

294

been studied, namely: configuration, coordination and procedural justice; c) Pinkse, Kuss and Hoffmann (2010) discuss the factors that influence the ability of multinational companies to implement a comprehensive environmental strategy; d) Wallace, Johnson and Umesh (2009) focus on the critical resources needed to overcome the alignment challenges of Multichannel Distribution - MCD; and e) Homburg, Krohmer and Workman Jr. (2004) address the role of intangible variables in implementing strategies.

We highlight that studies related to performance are traditional when it comes to strategy implementation, for the heart of the problem of implementation consists in determining the appropriate combination of factors that lead to positive results (HARRINGTON, 2006).

\section{- INTERPERSONAL VieW}

Strategy implementation may be influenced by some phenomena, such as the degree of understanding between the managers and the nature of communication between superiors and subordinates. In this sense, the authors explore what can foster consensus or information sharing on the strategy to be implemented. According to $\mathrm{Ho}, \mathrm{Wu}$ and $\mathrm{Wu}$ (2014), performance measures help to influence the consensus towards success in the strategy implementation process.

O'Reilyet al. (2010) proposes to study how senior leaders ensure that the group and organizational members implement their decisions. Sonenshein and Dholakia (2012) point out that managers and employees influence others in the process of change, albeit in different ways.

In alignment aspects, some authors consider strategy implementation, performance measurement and strategic alignment within a diverse group of companies (MICHELI; MURA; AGLIATI, 2011). Chimhanzi and Morgan (2005), in turn, present the study of alignment between the marketing and human resources departments.

Hakonssonet al. (2012) demonstrates how and when the executive style affects the strategy implementation and the consequences of alignment or misalignment between the two. Ogbeide and Harrington (2011) studies how the degree of participation in various hierarchical levels impact the implementation success.

According to Sonenshein (2010), existing research neglect the dynamic interaction in the construction of meaning between managers and employees. By identifying this research gap, the author examines how the construction of meaning differs between managers and employees and how these differences are important for the process of change being implemented.

\section{- INDIVIDUAL VIIEW}

In this category the cognitive processes of managers involved are considered, the way managers interpret their roles and the level of commitment to the success of the implementation process. Klingebiel and Meyer (2013) illustrate how managers alternate between decision making styles for the implementation of change, i.e., how the decision to adapt to the courses of action. Sonenshein (2009), in turn, reports that recent research shows a greater interest in ethical issues. Huy (2011) studied the nature of the emotions of middle management, their social identities at work, and how they can be motivated towards strategic change.

We can observe that many topics evolve to current discussions of organizational environment and that should be considered in research on strategy implementation, such as: social networks (KLEINBAUM; STUART, 2014); collective cognitive process of organizational agents during the implementation of strategic change (GUIETTE; VANDENBEMPT, 2013); alternation between decision making styles during implementation (KLINGEBIEL; MEYER, 2013); sensemaking of those involved in the change process (SONENSHEIN; DHOLAKIA, 2012); and the nature of the emotions of middle management, their social identities at work, and how they can be motivated towards strategic change (HUY, 2011). 
The issues raised in the three views also depends on contextual variables. In this manner, we present the interest in knowing the BRICS, for the investigation of how strategies can be implemented in organizations that are part of this context.

\subsection{CHARACTERISTICS OF THE BRICS}

This section discusses the main characteristics of the countries present in the BRICS, considering the economic, social, cultural and ethnical aspects identified (SHETH, 2011).

The term BRIC was created in 2001, by the economist Jim O'Neill from the Goldman Sachs Bank, due to the economic representation of the following countries: Brazil, Russia, India and China. In 2009, South Africa was incorporated to this group, thus becoming BRICS. More than an acronym that identifies countries in the ascendant in the international economic order, BRICS has become a promising political and diplomatic entity (MINISTÉRIO DAS RELAÇÕES EXTERIORES, 2015).

Table 2 presents the articles contemplated in the systematic review on the BRICS characteristics. Following, we discuss their contributions.

\section{- ECONOMICAL ASPECTS}

The countries present in the BRICS offer vast business opportunities for the rest of the world, due to the existence of markets with high potential and fast economic growth (CHAN; DAIM, 2012). It is characterized as a leader in the development of new products and services, besides influencing other countries, through trade and technology transfer (CHIRCU; MAHAJAN, 2009).

However, these countries still have some economic deficiencies, such as India, for instance, which has a large number of private companies, fact that negatively influences the modernization of enterprises, considering the amount of capital available for investment. In India, the existence of fraud and the inadequacy of banks to provide funds to the private sector emphasizes the need for development of the capital market and the financial market as a whole (SNOWDEN; MUÑOZ, 2012).

In China, in turn, there is a large number of publicly listed state-controlled companies, with political interference as a very important institutional characteristic, which is also present in the other countries of the BRICS (LI; ZHANG, 2010). The frequent presence of state controlled enterprises in emerging markets affects the economies of these countries, since these companies tend to be less innovative than the others, negatively influencing in obtaining external resources and in the capacity to face foreign competition (AYYAGARI; KUNT; MAKSIMOVIC, 2011). Another characteristic that affects the economy of these countries is the practice of bribery, which increases on average $5 \%$ the cost of doing business for companies (ZHOU; HAN; WANG, 2013).

Given the weakness of formal institutions present in emerging economies, enterprises established in those places are often valued for their credibility. Zhang and Rezaee (2009) identified that the credibility of Chinese enterprises have a positive relationship with performance, showing that companies with a superior reputation have a lower cost than the other, due to the lower risk posed.

In relation to the consumers in these countries, we can say that they are characterized as materialistic, that at the same time are concerned about issues related to sustainability and environmental protection, and they are willing to meet the appeals related to the supply of sustainable products (STRIZHAKOVA; COULTER, 2013).

It is interesting to note that the diversified and familiar conglomerates, represents from 80 to $85 \%$ of the total value of private sector sales in these economies. Whilst there is a tendency of strategic reorientation in developed markets, in emerging economies the scenario 
BBR

14,3

296

is dominated by conglomerates, such as the Tata Group, in India and the Carso Group, in Mexixo (PURKAYASTHA; MANOLOVA; EDELMAN, 2012). Please note that the investments of foreign companies and groups in emerging economies are beneficial, for they assist in the access to knowledge, increasing productivity, as well as creating a learning environment for local businesses, contributing to their innovation and technological capacity (LI; CHEN; SHAPIRO, 2013; ZHANG ET AL., 2010; ZHANG; LI; LI, 2014).

\section{- Social ASPECTS}

These countries have transitional and weak innovation systems, when compared to developed countries and are characterized as latecomers in the development of technologies (CHAN; DAIM, 2009).

It is known that these markets have several weaknesses with regard to the infrastructure, education, health and income distribution, however we identified a few positive prospects in the studies analyzed. Among them, we can highlight the trend described by Chircu and Mahajan (2009), who studied aspects related to mobile technology in these countries. The authors infer that these countries can overcome the path dependence related to low income, infrastructure and the educational level and surprise by the communication via mobile technology.

The authors also comment that unlike consumers in developed countries seeking state of the art technology services, BRICS consumers focus on low-cost devices and that the mobile and internet technology, along with business practices, as microcredits and door to door sales, can promote economic growth even in the poorest areas.

As discussed, a significant portion of consumers in these countries search for low-cost products and services, however, managers of corporations should consider that another portion of these consumers, present in global and "glocal" segments, have achieved higher education, likes to travel and use the internet. In addition, they are concerned with issues related to sustainability and takes this into consideration when purchasing goods and services (STRIZHAKOVA; COULTER, 2013).

In the business scope, we highlight that the presence of foreign companies in emerging economies has contributed to the improvement of laws and regulations related to human resources management, issue that is often discussed in several developing countries such as China (PURKAYASTHA; MANOLOVA; EDELMAN, 2012).

In this sense, Khavul, Benson and Datta (2010) identified that the most rigorous standards imposed by foreign origin companies have pressured local businesses to invest in human resources management, as well as encouraging the adhesion of practices adopted in foreign markets.

\section{- Cultural and Ethnical Aspects}

Chircu and Mahajan (2009) describe that to achieve success in these countries it is necessary to change the mentality on the development of new products and services, which is usually centered on the economy of developed countries. The authors point out that managers of organizations must consider cultural and ethnical aspects of these countries to assess the supply of products and services.

In addition to these aspects, we should consider the cultural characteristics of the business being conducted in those countries, both as regards to the behavior of managers, as the characteristics of relations with other stakeholders (ZHOU; HAN; WANG, 2013).

In this sense, McCarthy et al. (2012) describe the use of favors to achieve business objectives is a common practice in these countries and that one of the causes of this behavior is the weak legitimacy of formal institutions. In these countries, favors are used to achieve various objectives, such as: physical goods, licenses and permits and referrals of potential 
customers, suppliers and partners (MCCARTHY ET AL., 2012). The authors said that the practice of using favors can lead to the use of bribery.

For Zhou, Han and Wang (2013), the abnormal behavior of some managers, which result in corruption and bribery are the result of the inequality in opportunity and access to resources by enterprises, leading managers to avoid/reduce payment rates and ignore laws or regulations, to ensure the survival of organizations. Purkayastha, Manolova and Edelman (2012) also contribute in this discussion, describing that the causes of opportunism, bribery and corruption, present in emerging markets, are the restrictions to negotiations, such as: the absence of intermediary institutions, well-defined property rights and of a legal well founded model.

We highlight that the managers of enterprises established in those countries consider the use of favors as ethical acts, which can be seen as unethical by active managers in developed countries due to different cultural values (MCCARTHY ET AL., 2012; ZHOU; HAN; WANG, 2013).

Another hindering characteristic of these markets is the existence of fraud in the financial market, which highlights the need to develop transparent mechanisms (SNOWDEN; MUÑOZ, 2012). In addition to agency problems, which are frequent and are configured as a concern of governments of emerging countries (HO; WU; XU, 2011; LI; ZHANG, 2010).

\section{DISCUSSION OF RESULTS}

Organizations are political and cultural systems, and changes must be examined in their context, comprising the social, economic, political and competitive environment in which they operating (PETTIGREW, 1992). It is believed that to compete in the countries comprising the BRICS, as well as in other economic contexts, companies need to adapt to the new environment and prepare for strategic changes, since in this process, it is necessary to know the external environment, and the internal, for the new strategy must be adapted to market conditions (OKUMUS, 2003).

We identified that the topics explored in strategy implementation seem to extrapolate the initial classification proposed by Noble and Mokwa (1999), for in the individual view initially proposed, aspects such as the sensemaking of those involved in the change process, were not considered; already in the interpersonal process view, at first, we did not consider the teams and the collective cognitive process (perspective that has been more recurrent with flexible organizational structures and the increasing use of multidisciplinary teams); and in the structural vision process, social networks emerge, elements not listed in the initial classification.

Given the strategy implementation aspects presented by the authors we analyzed in this systematic review, Figure 1 presnts a proposal for a summarization of the findings, considering the influence of internal and external factors in the trajectory of the strategy being implemented.

Figure 1 suggests that the strategy implementation theme involves internal and external organizational aspects, and both, are observed by the coevolution approach, are also relevant in the strategy implementation process. In the internal sphere the new perspectives presented by the analyzed studies were incorporated into the analysis.

In the structural view, we highlight the role of social networks, so common nowadays, and that should not be neglected when the organizational structure is studied. In the interpersonal view, we observe the need to understand the cognitive process of the team responsible for the implementation, including the understanding of the feelings and mutual perceptions of the strategy to be implemented. At the behavioral level, both feelings, like sensemaking have been relegated as a secondary plan. These factors point to an update on the research agenda proposed by Noble and Mokwa (1999). 
BBR

14,3

298

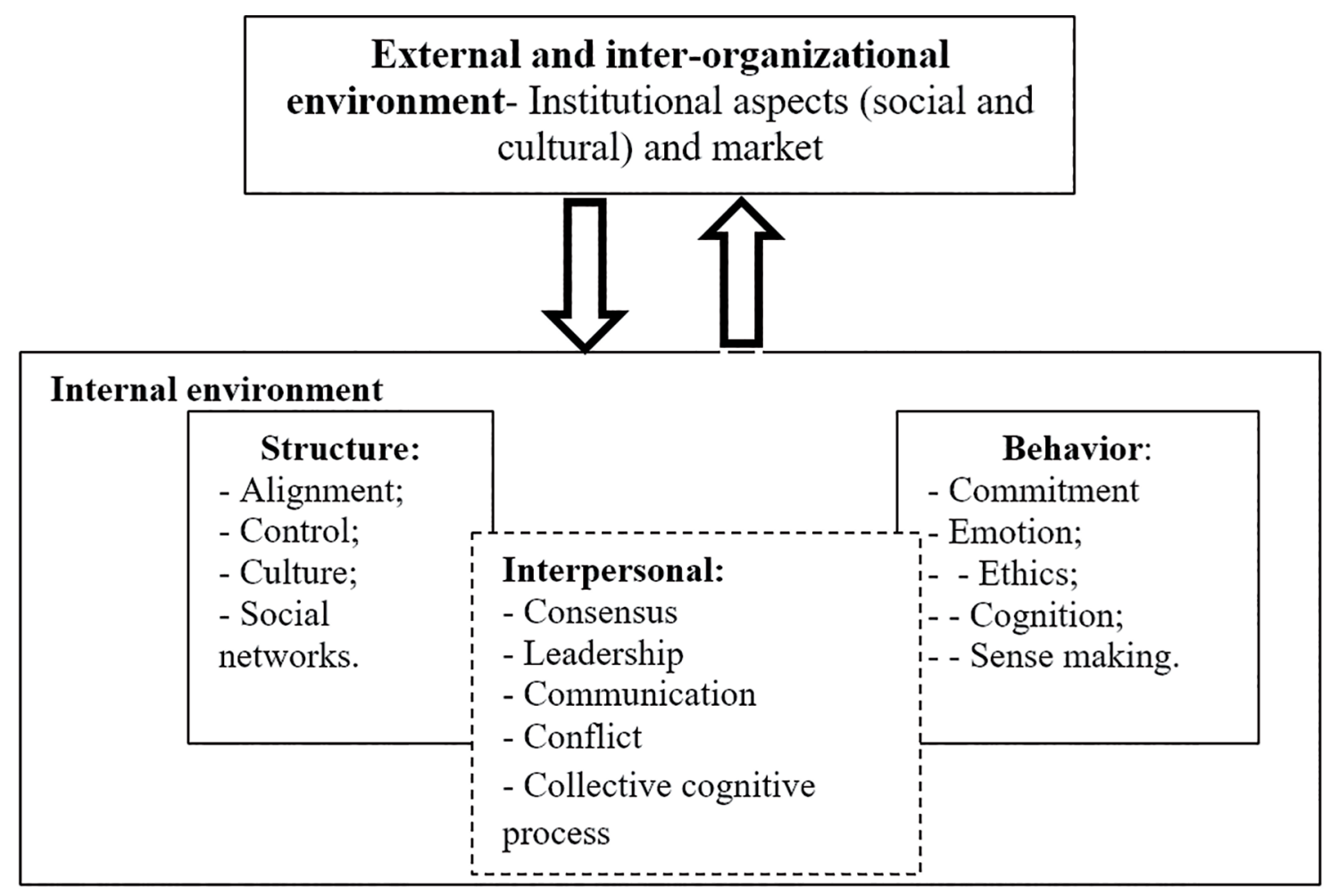

Figure 1. Strategy Implementation: Internal and External Environment. Source: The authors, (2015).

By analyzing the characteristics of the BRICS, as well as the identification of research gaps in strategy implementation, there is a need to reconcile the emerging needs of the current organizational environment and the exploration of how the organization can meet the context analysis. The relationship established in the review process supports a research agenda, since it emphasizes the perspective of institutional problems that are not verified in developed economies and that characterize the empirical field in the case of the BRICS. The proposition of research drivers for the field is presented in Table 3.

The analysis that originates in the research agenda indicates the existence of specific factors of emerging economies such as the BRICS, which are not currently included in the studies on strategy implementation. The economic, social, cultural and ethnic characteristics present in these contexts may provide, as mentioned in the previous analysis, an advance in understanding the strategy implementation process. Some aspects emerge, such as: a) the weak legitimacy of formal institutions; b) low social and technological development; c) peculiarities of organizational management; d) social and environmental factors related to the consumption, among others. On the other hand, research on implementation strategy needs to consider, among other aspects, contemporary characteristics of the internal organizational environment, such as: a) social networks; b) emotional aspects and the construction of meaning (sensemaking) of individuals; and c) mutual perceptions of those involved in the implementation process.

By relating environment and organization, it is understood that the precepts of coevolution, which is the combined result of management intentionality and environmental effects were achieved, because the context of the BRICS, which differs from the developed economies, has an influence on the implementation of organizational strategies. Consequently, organizations established in the context of the BRICS influence the environment (PURKAYASTHA; MANOLOVA; EDELMAN, 2012; KHAVUL, BENSON AND DATTA, 2010), demonstrating that institutions coevolve, i.e, they influence their 
Table 3. Research agenda on strategy implementation in the context of the BRICS

Economic aspects

Social aspects

Cultural and ethnical aspects

To study the relationship

with markets in which:

technology access is

restricted, there is state

To analyze organizational

Structural view

structures configurations

and control mechanisms,

destined to operate with

institutional problems.

interference in businesses,

there is shortage of

resources and innovation

systems are weak.

\begin{tabular}{|c|c|}
\hline Interpersonal view & $\begin{array}{l}\text { To examine how the } \\
\text { management can promote } \\
\text { interpersonal relationships } \\
\text { in scenarios with constant } \\
\text { changes, rapid economic } \\
\text { growth and institutional } \\
\text { problems. }\end{array}$ \\
\hline Individual view & $\begin{array}{c}\text { To explore which } \\
\text { individual behaviors } \\
\text { should be encouraged to } \\
\text { enable the organization } \\
\text { to change, considering } \\
\text { scenarios with fragile } \\
\text { institutions, troubled } \\
\text { political relations and high } \\
\text { risk. }\end{array}$ \\
\hline
\end{tabular}

To explore interpersonal aspects that can exert influence on relationships and internal and external communication, in different societies, improving the

understanding of actions to change, ensuring stability and alignment.

To understand personal aspects of those involved in the change process (sensemaking, feelings, ethics) that can affect relationships in scenarios where individuals explore different alternatives, due

to new possibilities of social mobility.

To analyze local cultural and ethical issues that may influence the organizational structure.

To analyze implementation processes that support the strategic consensus and promote leadership styles committed to change, considering scenarios in which business practices are peculiar.

To explore ways to implement change with a focus on understanding individual aspects (sensemaking, feelings, ethics), from the local culture, which can affect the way individuals understand their role in the organization.

Source: The authors, (2015).

environment and the environment influences the organization, a recursive two-way view of mutual causality (LEWIN; VOLBERDA, 1999).

\section{FINAL CONSIDERATIONS}

This study aimed at identifying research suggestions in strategy implementation and relate them to the characteristics of the countries belonging to the BRICS. As a result, we highlight the originality of this study, since some studies analyze the strategy implementation thematic or the economic context of the countries belonging to the BRICS, however, a study that has linked these themes is unknown.

To achieve the proposed objective, we conducted a systematic review, which allowed us to verify that there is a wide range of opportunities for research that, on the one hand, explore the characteristics comprising the alliance of countries of the BRICS and that, on the other hand, in the field of strategy, allow the proposed research suggestions by the authors analyzed. It is worth noting that this study contributes by demonstrating the existence of research gaps, regarding the understanding of factors external to the organization that influence the strategy implementation process in those countries, highlighting the need for research efforts that unite the themes studied. 
BBR

14,3

It is noteworthy that the authors of the strategy implementation thematic came to realize the need to update the research agenda, by suggesting future studies that address the characteristics of current organizational environments, beckoning the need to understand both new organizational structures, as peculiarities of the process of individual and collective meaning construction. These aspects, seen from the perspective of coevolution, influence and are influenced by the organizational macro environment. As an organizational macro environment, we analyzed the context of the BRICS, in which were identified economic, social, cultural and ethnical characteristics which can contribute to an advance in understanding the strategy implementation process in these economies.

We believed that this study presents clear academic and managerial implications. In the scientific scope, there is an initial contribution to the research efforts in the strategy implementation field, in revealing what current research, published in scientific journals with high impact factor, have presented as relevant to the thematic. In addition, it contributes by updating a discussion on the research paths of strategy implementation.

Finally, in considering the BRICS context, bringing forth gaps that may offer new perspectives for the understanding of the research field. These contributions of the study culminated in the updating of the research agenda in strategy implementation.

In the management scope, on the other hand, the study contributes by exploring the discussion of the characteristics that make the BRICS a different context for the implementation of the strategy, when compared to developed economies. This allows managers of companies established in those countries or those who wish to operate in them, to better understand the context of these economies and identify aspects that should be considered so that scenarios may be read and to implement strategic decisions.

This research also has some limitations signaling opportunities for future studies. The selection of some databases and keywords, for example, can be characterized as limitations. Thus, future research could extend and/or modify the characteristics of this systematic review, including the emerging powers in the scope, since the BRICS, according to Jacob and Rossem (2014), cannot be considered in such a category.

\section{REFERENCES}

*AYYAGARI, M.; KUNT-DEMIRGUÇ, A.; MAKSIMOVIC, V. Firm Innovation In Emerging Markets: The Role Of Finance, Governance, And Competition. Journal of Financial and Quantitative Analysis. 46, n. 6, 1545-1580, 2011.

*BHIMANI, Alnoor; LANGFIELD-SMITH, Kim. Structure, formality and the importance of financial and non-financial information in strategy development and implementation. Management Accounting Research. 18, n.1, 3-31, 2007.

BIGNETTI, L. P.; PAIVA, E. L. Ora (Direis) ouvir estrelas!: estudo das citações de autores de estratégia na produção acadêmica brasileira. RAC. 6, n. 1, 105-125, 2002.

*BRENES, E. R.; MENA, M.; MOLINA, G. E.Key success factors for strategy implementation in Latin America. Journal of Business Research.61, n. 6, 590-598, 2008.

*CHAN, Leong; DAIM, Tugrul. Exploring the impact of technology foresight studies on innovation:Case of BRIC countries. Futures, 44, 618-630, 2012.

CHILD, J. Strategic Choice in the Analysis of Action: Structure Organizations and Environment:Retrospect and Prospect. Organization Studies. v. 18, n. 1, p. 43-76, 1997.

*CHIMHANZI, J. MORGAN, R. Explanations from the marketing/human resources dyad for marketing strategy implementation effectiveness in service firms. Journal of Business Research. 58, 787- 796, 2005.

*CHIRCU, Alina M.; MAHAJAN, Vijay. PERSPECTIVE: Revisiting the Digital Divide: An Analysis of Mobile Technology Depth and Service Breadth in the BRIC Countries. The Journal of Product Innovation Management.26, 455-466, 2009.

*CRITTENDEN, V. L.; CRITTENDEN, W. F. Building a capable organization: The eight levers of strategy implementation. Business Horizons. v. 51, n.4, p. 301-309, 2008. 
*FRYXELL, G. E.; BUTLER, J.; CHOI, A. Successful localization programs in China: an important element in strategy implementation. Journal of World Business. 39, 268-282, 2004.

*GARY, M. S. Implementation Strategy and performance outcomes in related diversification. SMJ. 26, 643-664, 2005.

*GUIETTE, A.; VANDENBEMPT, K. Exploring team mental model dynamics during strategic change implementation in professional service organizations. A sensemaking perspective. European Management Journal. 31, 728-744, 2013.

*HAKONSSON, D. D.; BURTON, R. M.; OBEL, B.; LAURIDSEN, J. T. Strategy Implementation Requires the Right Executive Style: Evidence from Danish SMEs. Long Range Planning. 45, 182-208, 2012.

*HARRINGTON, Robert J. The moderating effects of size, manager tactics and involvement on strategy implementation in foodservice. International Journal of Hospitality Management. 25, n. 3, 373-397, 2006.

*HOMBURG, C.; KROHMER, H.; WORKMAN Jr., J. P. A strategy implementation perspective of market orientation. Journal of Business Research. v.57, p. 1331- 1340, 2004.

*HO, J. L. Y.; WU, A.; XU, S. X. Corporate Governance and Returns on Information Technology Investment: Evidence From an Emergent Market. SMJ.32, 595-623, 2011.

HO, J. L. Y.; WU, A.; WU, S. Y. C. Performance measures, consensus on strategy implementation, and performance: Evidence from the operational-level of organizations. Accounting, Organizations and Society. n. 39, p. $38-58,2014$.

HREBINIAK, Lawrence G. Obstacles to Effective Strategy Implementation. Organizational Dynamics, 35, n. 1, 12-31, 2006.

*HUY, Q. N. How middle managers' group-focus emotions and social identities influence strategy implementation. SMJ.32, n. 13,1387-1410, 2011.

JACOB, L. M.; ROSSEM, R. V. The BRIC Phantom: A comparative analysis of the BRICs as a category of rising powers. Journal of Policy Modeling. 36, 47-66, 2014.

*KAZMI, Azhar. A proposed framework for strategyimplementation in the Indian context. Management Decision. 46, n. 10, 1564-1581, 2008.

KHAVUL, S., BENSON, GEORGE S., DATTA, D. K.. Is Internationalization Associated With Investments In Hrm? A Study Of Entrepreneurial Firms In Emerging Markets. Human Resource Management. 49, n. 4, $693-713,2010$.

*KLEINBAUM, A. M.; STUART, T. E. Inside the Black Box of the Corporate Staff: Social Networks and the Implementation of Corporate Strategy. SMJ. n. 35, p. 24 - 47, 2014.

*KLINGEBIEL, R.; MEYER, A. de. Becoming Aware of the Unknown: Decision Making During the Implementation of a Strategic Initiative. Organization Science. 24, 133-153, 2013.

LEONARDI, P. M. Materializing Strategy: The Blurry Line between Strategy Formulation and Strategy Implementation. British Journal of Management. v. 26, p. 17- 21, 2015.

LEWIN, A. Y.; VOLBERDA, H. W. Prolegomena on Coevolution: A Framework for Research on Strategy and New Organizational Forms. Organization Science. v. 10, n. 5, p. 519-534, 1999.

*LI, J.;CHEN, D.; SHAPIRO, D. M. FDI Spillovers at the National and Subnational Level: The Impact on Product Innovation by Chinese Firms. Management and Organization Review.9, n.3, 413-435, 2013.

*LI, Wenjing; ZHANG, Ran. Corporate Social Responsibility, Ownership Structure, and Political Interference: Evidence from China. Journal of Business Ethics, 96, 631-645, 2010.

*LIN, Shao-Lung; HSIEH, An-Tien. International strategy implementation: Roles of subsidiaries, operational capabilities, and procedural justice. Journalof Business Research. 63, 52-59, 2010.

MACHADO-DA-SILVA, C. L; FONSECA, V. S. da; FERNANDES, B. H. R. Mudança e Estratégia nas Organizações: Perspectivas Cognitiva e Institucional. Anais... Enanpad, 1998.

*MCCARTHY, Daniel J.; PUFFER, Sheila M.; DUNLAP, Denise R.; e JAEGER, Alfred M. A Stakeholder Approach to the Ethicality of BRIC-firmManagers' Use of Favors. Journal of Business Ethics, 109, 27-38, 2012.

*MICHELI, Pietro; MURA, Mateo; AGLIATI, Marco. Exploring the roles of performance measurement systems in strategyimplementation The case of a highly diversified group of firms. International Journal of Operations \& Production Management. 31, n. 9, 1115-1139, 2011.

MINISTÉRIO DAS RELAÇÕES EXTERIORES. Informação sobre o BRICS. Disponível em: http:// brics6.itamaraty.gov.br/pt_br/sobre-o-brics/informacao-sobre-o-brics. Acesso em 22 de junho de 2015. 
BBR

14,3

MINTZBERG, H.; AHLSTRAND, B.; LAMPEL, J. Safári de Estratégia. Porto Alegre: Bookman, 2000.

*NARANJO-GIL, David; HARTMANN, Frank. How CEOs use management information systems for strategy implementation in hospitals. Health Policy. 81, 29-41, 2007.

*NIXON, R. D.; HITT, MICHAEL, A.; LEE, H.; EUI. J. Market reactions to announcements of corporate dowssizing actions and implementations strategies. SMJ. 25, 1121-1129, 2004.

NOBLE, C. H.; MOKWA, M. R. Implementing Marketing Strategies: Developing and Testing a Managerial Theory. Journal of Marketing. 63, 57-73, 1999.

NOBLE, Charles H. The Eclectic Roots of Strategy Implementation Research. Journal of Business Research.45, 119-134, 1999.

*OGBEIDE, Godwin-Charles A.; HARRINGTON, Robert J. The relationship among participative management style, strategy implementation success, and financial performance in the foodservice industry. International Journal of Contemporary Hospitality Management. 23, n. 6, 719-738, 2011.

OKUMUS, F. A Framework to Implement Strategies in Organizations. Management Decision. 41, n. 9, 871-882, 2003.

*O'REILLY, Charles A.; CALDWEL, David F.; CHATMAN, Jennifer A.; LAPIZ, Margaret; SELF, William. How leadership matters: The effects of leaders' alignment on strategy implementation. The Leadership Quarterly. 21, 104-113, 2010.

*PINKSE, Jonatan; KUSS, Matthias J.; HOFFMANN, Volker H. On the implementation of a 'global' environmental strategy: The role of absorptive capacity. International Business Review.19, 160-177, 2010.

*PURKAYASTHA, Saptarshi; MANOLOVA; Tatiana S.; EDELMAN, Linda F. Diversification and Perfomance in Developed and Emerging Market Contexts: A Review of the Literature. International Journalof Management Reviews. 14, 18-38, 2012.

SAMPAIO, R.; MANCINI, M. Estudos de revisão sistemática: um guia para a síntese criteriosa da evidência científica. Revista Brasileira de Fisioterapia, 11, n. 1, 83-89, 2007.

SCHENDEL, D. (1991). Introduction to the special issue on global strategy. SMJ.12, 1-3, 1991.

SHETH, Jagdish N. Impact of Emerging Markets onMarketing: Rethinking ExistingPerspectives and Practices. Journal of Marketing, 75, 166-182, 2011.

SKIVINGTON, J. E.; DAFT, R. A Study of Organizational 'Framework' and 'Process' Modalities for the implementation of business-level strategic decisions. Journal of Management Studies. 28, 1991.

*SLATER, S. F.; OLSON, E. M.; HULT, T. M. Worried about strategy implementation? Don't overlook marketing's role. Business Horizons. 53, 469 - 479, 2010.

SMITH, Brian D. Maybe I will, maybe I won't: what the connected perspectives of motivation theory and organisational commitment may contribute to our understanding of strategy implementation. Journal of Strategic Marketing. 17, No. 6, 473-485, 2009.

*SONENSHEIN, SCOTT. Emergence of Ethical Issues During Strategic Change Implementation. Organization Science. 20, n. 1, 223-239, 2009.

*__ We're changing - or are we? Untangling the role of progressive, regressive, and stability narratives during strategic change implementation. AMJ53, No. 3, 477-512, 2010.

*SONENSHEIN, S.; DHOLAKIA, U. Explaining Employee Engagement with Strategic Change Implementation: A Meaning-Making Approach. Organization Science. 23, n.1, January-February, 2012.

*SNOWDEN, Nicholas; MUÑOZ, Jesús. Building a BRIC? Stock Market Opening and Investment Finance in India since Liberalization. World Development, 40, $\mathrm{n}^{\circ} .6$ 1109-1121, 2012.

*STRIZHAKOWA, Yulika; COULTER, Robin A. The "green" side of materialism in emerging BRIC and developed markets:The moderating role of global cultural identity. International Journal of Research in Marketing, 30, 69-82, 2013.

THORPE, E. R.; MORGAN, R. E. In pursuit of the "ideal approach" to successful marketing strategyimplementation. European Journal of Marketing. 41, n. 5/6, 659-677, 2007.

*WALlACE, D. W.; JOHNSON, J. L.; UMESH, U. N. Multichannels Strategy Implementation: The Role of Channel Alignment Capabilities. Decision Sciences. 40, n. 4, 2009.

XU, D.; MEYER, K. Linking Theory and Context: 'Strategy Research in Emerging Economies' after Wright et al. (2005). Journal of Management Studies. 50, n.7, 2013.

*YE,Jun; MARINOVA, Detelina; SINGH, Jagdip . Strategic Change Implementation and Performance Loss in the Front Lines. Journal of Marketing. 71, 156-171, 2007.

*YE, Kangtao; ZHANG, Ran. Do Lenders Value Corporate Social Responsibility?Evidence from China. Journal of Business Ethics, 104, 197-206, 2011. 
*ZHANG, Ran; REZAEE, Zabihollah. Do Credible Firms Perform Better in Emerging Markets? Evidence from China. Journal of Business Ethics, 90, 221-237, 2009.

*ZHANG, Y. A.; LI, Y.; LI, H. FDI Spillovers Over Time In An Emerging Market: the Roles of Entry Tenure and Barriers To Imitation. AMJ. 57, n. 3, 698-722, 2014.

*ZHANG, Y., LI, H.; LI, Y.; ZHOU, LI-AN. FDI spillovers in an emerging market: the role of foreign firms' country origin diversity and domestic firms' absorptive capacity. SMJ. 31, 969-989, 2010.

*ZHOU, Xiaoyu; HAN, Yi; WANG, Rui. An Empirical Investigation on Firms' Proactive and Passive Motivation for Bribery in China. Journalof Business Ethics, 118, 461-472, 2013. 